\title{
Larangan Pengunggahan Konten Terkait FPI: Tinjauan Perspektif Hak Asasi Manusia di Indonesia
}

\author{
Muhammad Fauzi ${ }^{\circledR}$, Mellayanah², Muhammad Akmal Rizki Rivaldi ${ }^{2}$, Fairuz Arta \\ Abhipraya ${ }^{4}$ \\ 1,3 Universitas Negeri Semarang \\ 2 Sekolah Tinggi Hukum Indonesia Jentera \\ 4 Universitas Muhammadiyah Yogyakarta \\ E-mail Korespondensi: muhammadfauzi698@students.unnes.ac.id
}

\begin{abstract}
The issuance of Chief Police Declaration No.1/Mak/I/2021 regarding to the Compliance with the Prohibition Activities, Use of Symbols and Attributes related to FPI (Islamic Defenders Front) has sparked a lot of debate while viewed from the aspect of Human Rights. In particular, Article $2 d$ of the declaration prohibits accessing, uploading and disseminating FPI-related content on the Internet which has made society and press make this thing as a hot topic to demand their free of expression as element of human rights. This study aims to examine the prohibition of uploading content related to FPI in article $2 d$ of the Chief of Police's declaration No.1/Mak/I/2021 in according to human right principles. The research method has used is normative juridical with a statutory and conceptual approach. The data source that used is secondary data from laws and regulations of human rights and other written sources. Article $2 d$ in the Chief of Police's declaration No.1/Mak/I/2021 exceeded the principles of limiting human rights based on the siracusa principle and the three-part-test. Article $2 d$ of this declaration also threatens the freedom of journalists and media who has a main task to disseminating fact information to the public. The National Police Chief should have updated this declaration to the intent and purpose of this issuance declaration, or revoke article $2 d$ in which considered have limited freedom of expression as an element of human rights, so that all legal actions in this country are in accordance with the principles of the rule of law and human rights.
\end{abstract}

Keywords: human rights, freedom of expression, freedom of pers

\section{Abstrak}

Dikeluarkanya maklumat Kapolri No. 1/Mak/I/2021 tentang Kepatuhan Terhadap Larangan Kegiatan, Penggunaan Simbol dan Atribut serta Pengehtian Kegiatan FPI (Front Pembela Islam) telah memicu banyak perdebatan jika ditinjau dari aspek HAM (Hak Asasi Manusia). Khususnya pada Pasal 2d dalam maklumat tersebut yang melarang untuk mengakses, mengunggah, dan menyebarluaskan konten terkait FPI di Internet yang telah membuat masyarakat sipil dan kelompok pers menjadikan hal ini sebagai topik hangat untuk menuntut kebabasan berekspresi sebagai salah satu elemen HAM. Penelitian ini bertujuan untuk mengetahui ada tidaknya pelanggaran serta hal-hal yang tidak sesuai dengan kaidah hak asasi manusia dalam larangan pengunggahan konten terkait FPI dalam pasal 2d maklumat Kapolri No. 1/Mak/I/2021. Adapun metode penelitian yang digunakan adalah yuridis normatif dengan pendekatan undang-undang dan konseptual. Sumber data yang digunakan adalah data sekunder dari peraturan perundangundangan terkait HAM, buku, artikel, maupun sumber tertulis lainya. Dalam penelitian ini ditemukan bahwa pasal 2d maklumat tersebut melampaui kaidah pembatasan hak asasi manusia berdasarkan prinsip siracusa dan uji tiga rangkai (three part test). Lebih jauh lagi, pasal $2 \mathrm{~d}$ pada maklumat tersebut juga mengancam kebebasan pers dari jurnalis dan media yang bertugas menyebarluaskan informasi kepada publik. Semestinya Kapolri memperbaharui maklumat tersebut sesuai maksud dan tujuan maklumat tersebut diterbitkan, atau setidaknya mencabut pasal $2 \mathrm{~d}$ dalam maklumat tersebut yang dianggap telah membatasi kebebasan bereskpresi sebagai elemen dari HAM. Hal ini agar seluruh tindakan hukum yang ada di negara ini sesuai dengan prinsip negara hukum dan hak asasi manusia.

Kata kunci: hak asasi manusia, kebebasan berekspresi, kemerdekaan pers 


\section{Pendahuluan}

Hak asasi manusia (HAM) merupakan hak yang melekat pada diri manusia sejak lahir. Hak ini merupakan hak yang dengan alasan apapun tidak dapat dilenyapkan dalam diri manusia karena pada hakikatnya ia manusia. ${ }^{1}$ Maka dari itu, HAM harus ada bukan karena semata-mata diatur dalam hukum positif, melainkan karena berdasarkan martabat seseorang sebagai manusia. HAM bersifat universal dan abadi, sehingga harus dilindungi, dihormati, dan dipenuhi, serta tidak boleh diabaikan, dikurangi, atau dirampasoleh siapapun. Tugas penghormatan, perlindungan, serta pemenuhan HAM menjadi tangung jawab pemerintah, tetapi dibutuhkan juga peran dan partisipasi masyarakat. ${ }^{2}$

Dalam prinsip hukum dan HAM, negara merupakan pemangku kewajiban HAM (duty bearer) dan setiap individu dan kelompok masyarakat dalam naungan yurisdiksinya merupakan pemegang HAM (rights holder). ${ }^{3}$ Negara sebagai pemangku kewajiban HAM (duty bearer), memiliki kewajiban utama untuk menghormati (to respect), untuk memenuhi (to fulfill) dan untuk melindungi (to protect) HAM bagi warga negaranya. Sebagai pemegang HAM (rights holder), dalam hal ini adalah setiap individu dan kelompok masyarakat berhak atas HAM yang telah dijamin dan dipenuhi negara dalam pelaksanaan HAM baik secara nasional maupun internasional. 4

Sebagai negara hukum (rechtstaat), Indonesia tentu telah memiliki jaminan HAM di dalam konstitusinya. Jaminan HAM tersebut terdapat dalam Pembukaan UUD NRI 1945 alenia IV serta Bab XA UUD NRI 1945. Selain itu, pengaturan mengenai HAM di Indonesia juga telah diatur secara khusus dalam UU No. 39 Tahun 1999 tentang Hak Asasi Manusia. Tidak hanya terdapat pada konstitusi dan undang-undang tersebut. Indonesia telah banyak mengatur secara khusus ketentuan HAM tertentu dalam peraturan perundang-undangan. Seperti UU No. 40 Tahun 1999 tentang Pers yang mengatur kemerdekaan pers sebagai suatu wujud kedaulatan rakyat dan menjadi unsur yang sangat penting untuk menciptakan kehidupan bermasyarakat, berbangsa dan bernegara yang demokratis, sehingga diharapkan kemerdekaan mengeluarkan pikiran dan pendapat dapat tercapai sebagai mana yang diatur dalam Pasal 28 UUD NRI 1945.

Dalam instrumen hukum internasional, HAM telah diatur dalam berbagai macam instrumen. Instrumen tersebut seperti Uniersal Declaration of Human Rights (UDHR) yang mencakup sekumpulan hak yang terdiri dari hak sipil, politik, budaya, sosial, ekonomi, serta beberapa hak kolektif tiap individu. Seiring dengan berkembangnya waktu, hak-hak yang telah disusun dalam UDHR, dituangkan dalam dua kovenan internasional yang mengikat secara hukum yakni International Covenant on Civil and Political Rights (ICCPR) serta International Covenant on Economic, Social and Cultural Rights (ICESCR). ${ }^{5}$ Dimana kedua kovenan internasional tersebut telah diratifikasi oleh Pemeritah Indonesia melalui UU No. 12 Tahun 2005 Tentang Pengesahan International Covenant on Civil and Political Rights (Kovenan Internasional Tentang Hak-Hak Sipil dan Politik) dan UU No. 11 Tahun 2005 Tentang Pengesahan International Covenant on Economic, Social and Cultural Rights (Kovenan Internasional Tentang Hak-Hak Ekonomi, Sosial Dan Budaya).

Pasal 4 ICCPR, memberikan kewenangan kepada negara untuk melakukan berbagai pembatasan HAM ketika negara dalam keadaan darurat yang esensial dan mengancam

Adnan Buyung Nasution, Arus Pemikiran Konstitusionalisme: Hak Asasi Manusia Dan Demokrasi, vol. 2 (Jakarta: Kata Hasta Pustaka, 2007), 44.

2 Tony Yuri Rahmanto, "Kebebasan Berekspresi dalam Perspektif Hak Asasi Manusia : Perlindungan, Permasalahan dan Implementasinya di Provinsi Jawa Barat", Jurnal Hak Asasi Manusia 7, no. 1 (2016): 46

3 Setiyani dan Joko Setiyono, "Penerapan Prinsip Pertanggungjawaban Negara terhadap Kasus Pelanggaran HAM Etnis Rohingya Di Myanmar," Jurnal Pembangunan Hukum Indonesia 2, no. 2 (2020): 263.

4 Faris Ghiffari dalam Ita Iya Pulina Perangin-angin, Rahayu, and Nuswantoro Dwiwarno, “Kewajiban Dan Tanggungjawab Negara Memberikan Perlindungan Hukum Terhadap Perempuan Korban Revenge Porn Di Indonesia," Diponegoro Law Journal 8, no. 1 (2019): 458.

5 Smith; Rhona K. M.; at.al., Hukum Hak Asasi Manusia (Yogyakarta: Pusat Studi Hak Asasi Manusia Universitas Islam Indonesia (PUSHAM UII), 2008), 91. 
Kosmik Hukum Vol. 21 No. 2 (2021): 86-97

E-ISSN: 2655-9242 | P-ISSN: 1411-9781

DOI: 10.30595/kosmikhukum.v21i2.9947

kehidupan suatu bangsa. ${ }^{6}$ Menurut Pengadilan Eropa untuk Hak Asasi Manusia, keadaan darurat (state of emergency) merupakan suatu krisis yang luar biasa yang memengaruhi keseluruhan penduduk dan merupakan ancaman bagi kehidupan komunitas yang terorganisir. ${ }^{7}$ Keadaan darurat dapat terjadi karena faktor yang timbul dari luar maupun dalam negeri. Dimana ancamannya dapat berupa ancaman bersenjata/militer, maupun tidak bersenjata yang menimbulkan korban jiwa dan merugikan harta benda di kalangan warga negara. ${ }^{8}$

Dengan dikeluarkannya Keputusan Bersama Menteri Dalam Negeri Republik Indonesia No. 220-4780 Tahun 2020, Menteri Hukum dan Hak Asasi Manusia Republik Indonesia No. M.HH-14.HH.05.05 Tahun 2020, Menteri Komunikasi dan Informatika Republik Indonesia No. 690 Tahun 2020, Jaksa Agung Republik Indonesia No. 264 tahun 2020, Kepala Kepolisian Republik Indonesia No. KB/3/XII/2020, dan Kepala Badan Nasional Penanggulangan Terorisme No. 320 Tahun 2020 tentang Larangan Kegiatan, Penggunaan Simbol, dan Atribut serta Penghentian Kegiatan Front Pembela Islam menjadi dasar pembubaran dan pelarangan aktivitas organisasi kemasyarakatan FPI secara hukum.

Menindaklanjuti keputusan bersama tersebut, Kepala Kepolisian Republik Indonesia (Kapolri) mengeluarkan Maklumat Kapolri No. 1/Mak/I/2021 tentang Kepatuhan Terhadap Larangan Kegiatan, Penggunaan Simbol dan Atribut serta Penghentian Kegiatan Front Pembela Islam (FPI). Dalam pasal 2d maklumat tersebut disebutkan bahwa masyarakat dilarang mengakses, mengunggah, dan menyebarluaskan konten terkait FPI baik melalui website maupun media sosial guna memberikan perlindungan dan menjamin keamanan serta keselamatan masyarakat. Namun, justru materi muatan dari pasal $2 \mathrm{~d}$ maklumat tersebut memicu kontroversi dan perdebatan di kalangan masyarakat. Hal tersebut dikarenakan pada materi pasal $2 \mathrm{~d}$ tersebut secara tidak langsung memberikan pembatasan hak kebebasan berekspresi dan hak atas informasi yang merupakan HAM setiap masyarakat.

Penelitian terkait kebebasan berkeskrpesi dan hak atas informasi yang merupakan HAM setiap masyarakat telah banyak dilakukan sebelumnya. Seperti penelitian yang dilakukan oleh Marwadianto dan Hilmi Ardani Nasution yang berjudul Hak Atas Kebebasan Berpedapat dan Berekspresi dalam Koriidor Penerapan Pasal 310 dan 311 KUHP yang pada dasarnya bertujuan menelusuri hak kebebasan berpendapat dan berekspresi dalam koridor hukum nasional terutama pada Pasal 310 dan 311 KUHP. Penelitian lain yang serupa dilakukan oleh Mufti Nurlatifah yang berjudul Persipangan Kebebasan Berekspresi dan Tanggung Jawab Sosial pada Regulasi Jurnalisme Digital di Indonesia yang bertujuan unuk menguraikan bagaimana implementasi kebebasan berekspresi dan tanggung jawab sosial pada Undang-Undang Informasi dan Transaksi Elektronik (UU ITE). Penelitian serupa memang telah banyak dilakukan. Namun, pada penelitian ini yang mengkaji secara khsusu terkait dampak Maklumat Kapolri No. 1/Mak/I/2021 tentang Kepatuhan Terhadap Larangan Kegiatan, Penggunaan Simbol dan Atribut serta Penghentian Kegiatan FPI terhadap kebebasan berekspresi dan hak atas informasi serta kebebasan pers belum pernah dilakukan oleh peneliti manapun.

Berdasarkan latar belakang masalah diatas, penelitian ini hendak menjawab permasalahan terkait dampak dari dikeluarkannya mengeluarkan Maklumat Kapolri No. 1/Mak/I/2021 tentang Kepatuhan Terhadap Larangan Kegiatan, Penggunaan Simbol dan Atribut serta Penghentian Kegiatan FPI yang dianggap memberikan pembatasan hak kebebasan berekspresi dan hak atas informasi yang merupakan HAM setiap masyarakat dan membatasi kebebasan dari pers atau jurnalis.

Maka dari itu, penelitian ini akan menguji Maklumat Kapolri No. 1/Mak/I/2021 tentang Kepatuhan Terhadap Larangan Kegiatan, Penggunaan Simbol dan Atribut serta Penghentian Kegiatan FPI terhadap peraturan perundang-undangan serta konsep-konsep hukum yang ada lebih lanjut. Penelitian ini penting dilakukan karena masyarakat Indonesia harus benar-benar dijamin hak asasinya serta tanpa diganggu gugat oleh siapapun bahkan oleh negara sekalipun.

\footnotetext{
Osgar S Matompo, "Pembatasan Terhadap Hak Asasi Manusia Dalam Prespektif Keadaan Darurat," Jurnal Media Hukum 21, no. 1 (2014): 59.

Nihal Jayawikrama dalam Ibid, 59.

A.H. Robertson dan J.G Merills dalam Ibid.
} 
Sekalipun negara memberikan pembatasan HAM kepada masyarakatnya, negara tidak boleh melampaui batas kewenangan yang diatur dalam instrumen-instrumen HAM yang ada.

\section{Rumusan Masalah}

Berdasarkan latar belakang yang telah dipaparkan, penelitian ini hendak menjawab pertanyaan terkait bagaimanakah dampak Maklumat Kapolri No. 1/Mak/I/2021 tentang Kepatuhan Terhadap Larangan Kegiatan, Penggunaan Simbol dan Atribut serta Penghentian Kegiatan FPI terhadap HAM setiap masyarakat serta bagaimanakah dampak Maklumat Kapolri No. 1/Mak/I/2021 tentang Kepatuhan Terhadap Larangan Kegiatan, Penggunaan Simbol dan Atribut serta Penghentian Kegiatan FPI terhadap kebebasan pers.

\section{Metode Penelitian}

Metode penelitian yang digunakan dalam penelitian ini adalah yuridis normatif. Penelitian hukum yuridis normatif merupakan penelitian yang ditujukan untuk menemukan dan merumuskan argumentasi hukum melalui analisis terhadap pokok permasalahan. ${ }^{9}$ Selain itu, penelitian ini disebut juga sebagai penelitian hukum kepustakaan yang dilakukan dengan cara meneliti bahan pustaka atau data sekunder belaka. ${ }^{10}$ Selanjutnya, pendekatan yang dilakukan dalam penelitian ini adalah Pendekatan undang-undang (statute approach) dan konseptual (conseptual approuch). Pendekatan undang-undang dilakukan dengan cara menelaah dan menganalisis semua undang-undang dan regulasi yang bersangkut tentang HAM, termasuk didalamnya terkait pembatasan HAM dan kebebasan pers. Kemudian, Pendekatan konseptual (conceptual approuch) dilakukan oleh peneliti manakala peneliti tidak menemukan indikator dari peraturan perundang-undangan yang terkait dengan HAM, dengan meneliti dan menganalisis buku, artikel, maupun sumber lain yang terkait dengan penelitian ini.Peneliti menggunakan teknik pengumpulan datadengan cara mempelajari peraturan perundang-undangan, buku, serta artikel yang berkaitan dengan penelitian. Data yang didapatkan dalam penelitian ini kemudian dianalisis dengan metode analisis data yuridis normatif pada umumnya. Hasil dari teknik pengumpulan data akan dicatat, dikumpulkan, dianalisis dan dikategorisasikan serta ditarik kesimpulan guna menemukan teori-teori secara umum yang berkaitan dengan penelitian ini.

\section{Hasil dan Pembahasan}

\section{Tinjaun Maklumat Kapolri No. 1/Mak/I/2021 dalam Perspektif Hak Asaasi Manusia}

Setiap manusia merupakan penyandang kepentingan, dimana berbagai kepentingan tersebut tidak dapat tercapai begitu saja dengan mudah, sebab kepentingan suatu individu bisa saja bertabrakan atau bahkan bertentangan dengan kepentingan individu lainnya. Seseorang akan lebih mudah menghadapi berbagai macam bahaya yang mengancam kepentingannya apabila ia hidup dalam masyarakat. Masyarakat dapat diartikan sebagai kehidupan bersama yang terorganisir untuk mencapai dan merealisasikan tujuan bersama. ${ }^{11}$ Hal ini juga sejalan dengan teori kontrak sosial menurut J.J Rosseau yang pada intinya menyatakan bahwa masingmasing individu melimpahkan segala hak perorangannya kepada komunitas masyarakat sebagai satu keutuhan. Dengan demikian, timbul hak dan kewajiban individu dalam bermasyarakat sehingga dapat mewujudkan kesejahteraan bersama.

Masyarakat merupakan elemen negara yang dilindungi dan dijamin hak serta kewajibannya dalam undang-undang. Indonesia sendiri telah menjamin hak asasi manusia

\footnotetext{
9 Philipus M. Hadjon dan Tatiek Sri Djamiati dalam Bachtiar, Metode Penelitian Hukum (Tangerang Selatan: Unpam Press, 2018), 56.

10 Soerjono Soekanto dan Sri Mamudji dalam Ibid.

11 Sudikno Mertokusumo, Mengenal Hukum Suatu Pengantar [Edisi Revisi] (Yogyakarta: Cahaya Atma Pustaka, 2010), 2.
} 
Kosmik Hukum Vol. 21 No. 2 (2021): 86-97

E-ISSN: 2655-9242 | P-ISSN: 1411-9781

DOI: 10.30595/kosmikhukum.v21i2.9947

seluruh masyarakat, Jaminan HAM tersebut terdapat dalam Pembukaan UUD NRI 1945 alenia IV serta Bab XA UUD NRI 1945. Selain itu, pengaturan mengenai HAM di Indonesia juga telah diatur secara khusus dalam UU No. 39 Tahun 1999 tentang Hak Asasi Manusia. Tidak hanya terdapat pada konstitusi dan undang-undang tersebut. Indonesia telah banyak mengatur secara khusus ketentuan HAM tertentu dalam peraturan perundang-undangan.

HAM pada hakikatnya merupakan hak yang dengan alasan apapun tidak dapat dilenyapkan dalam diri manusia karena pada hakikatnya ia manusia. ${ }^{12}$ Namun, tidak semua HAM bersifat absolut dan beberapa diantaranya bersifat fleksibel. Fleksibilitas HAM ini hanyalah sebuah kebutuhan praktis dan hukum serta tidak membuat HAM tersebut menjadi tidak penting jika dibandingkan dengan HAM lainnya. ${ }^{13}$ Karenanya beberapa HAM dapat dibatasi. Pembatasan HAM dilakukan untuk mengatur benturan antar hak, sebagai contoh kebebasan berekspresi harus memiliki suatu batasan untuk menghormati hak dan reputasi orang lain serta melindungi keamanan nasional, ketertiban umum, kesehatan, atau moral. ${ }^{14}$ Namun, perlu diingat bahwa pembatasan HAM harus dicantumkan dalam hukum nasional suatu negara, hal ini bertujuan agar masyarakat dianggap mengetahui pembatasan tersebut serta pelaksanaannya tidak boleh dilakukan dengan sewenang-wenang.

Pembatasan HAM dalam hukum dan HAM di Indonesia, diatur dalam Pasal 28J UUD NRI 1945, yang menyatakan bahwa setiap orang dalam menjalankan hak dan kebebasannya, wajib tunduk kepada pembatasan yang ditetapkan dengan undang-undang dengan maksud sematamata untuk menjamin pengakuan serta penghormatan atas hak dan kebebasan orang lain dan untuk memenuhi tuntutan yang adil sesuai dengan pertimbangan moral, nilai-nilai agama, keamanan, dan ketertiban umum dalam suatu masyarakat demokratis.

Salah satu hal yang menjadi kontroversi dan perdebatan di masyarakat terkait dengan pembatasan HAM adalah dengan dikeluarkannya Maklumat Kapolri No. 1/Mak/I/2021 tentang Kepatuhan Terhadap Larangan Kegiatan, Penggunaan Simbol dan Atribut serta Penghentian Kegiatan Front Pembela Islam (FPI) yang dikeluarkan sebagai tindak lanjut atas Keputusan Bersama Menteri Dalam Negeri Republik Indonesia No. 220-4780 Tahun 2020, Menteri Hukum dan Hak Asasi Manusia Republik Indonesia No. M.HH-14.HH.05.05 Tahun 2020, Menteri Komunikasi dan Informatika Republik Indonesia No. 690 Tahun 2020, Jaksa Agung Republik Indonesia No. 264 tahun 2020, Kepala Kepolisian Republik Indonesia No. KB/3/XII/2020, dan Kepala Badan Nasional Penanggulangan Terorisme No. 320 Tahun 2020 tentang Larangan Kegiatan, Penggunaan Simbol, dan Atribut serta Penghentian Kegiatan Front Pembela Islam yang menjadi dasar pembubaran dan pelarangan aktivitas organisasi kemasyarakatan FPI secara hukum. Di mana menurut Menteri Koordinator Bidang Politik, Hukum dan Kemanan, Mahfud MD, menyebutkan alasan dibubarkannya FPI karena FPI tidak mengurus berkas-berkas perpanjangan izin mendirikan organisasi ke Kementerian Hukum dan HAM sejak tahun 2019. Adapun permasalahan dalam Anggaran Dasar/Anggaran Rumah Tangga (AD/ART) FPI, yakni terkait pencatuman kata khilafah dalam AD/ART tersebut. ${ }^{15}$ Pembubaran FPI didasarkan pada UU No. 16 Tahun 2017 tentang Organisasi Kemasyarakatan (Ormas) yang dimaksudkan untuk menjaga eksistensi ideologi dan konsensus dasar negara, yakni Pancasila, UUD 1945, keutuhan NKRI, dan Bhinneka Tunggal Ika. ${ }^{16}$ Pemerintah menganggap FPI sebagai organisasi yang dapat mengancam ketertiban dan keamanan. Hal itu berkaitan dengan pengurus dan/atau anggota FPI, maupun yang pernah bergabung dengan FPI, berdasarkan data, sebanyak 35 orang terlibat tindak pidana terorisme. ${ }^{17}$

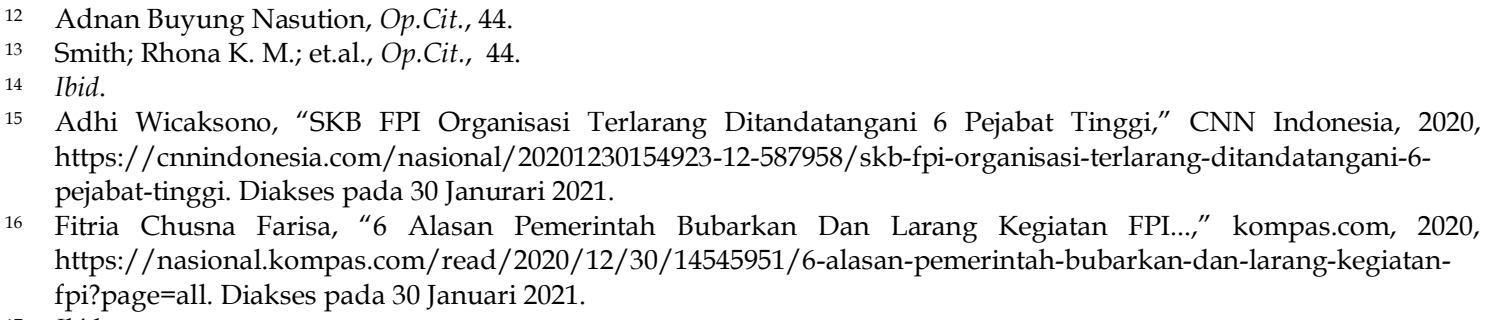

16 Fitria Chusna Farisa, "6 Alasan Pemerintah Bubarkan Dan Larang Kegiatan FPI...," kompas.com, 2020, https://nasional.kompas.com/read/2020/12/30/14545951/6-alasan-pemerintah-bubarkan-dan-larang-kegiatanfpi?page=all. Diakses pada 30 Januari 2021. 
Maklumat Kapolri No. 1/Mak/I/2021 sebagai tindak lanjut Keputusan Bersama tersebut dikeluarkan dengan tujuan untuk memberikan perlindungan dan mejamin keamanan serta keselamatan masyarakat. Salah satu pasal yang menjadi perdebatan dalam maklumat tersebut adalah pasal $2 \mathrm{~d}$. Dalam pasal $2 \mathrm{~d}$ maklumat tersebut disebutkan bahwa masyarakat dilarang mengakses, mengunggah, dan menyebarluaskan konten terkait FPI baik melalui website maupun media sosial guna memberikan perlindungan dan menjamin keamanan serta keselamatan masyarakat. Perdebatan itu terkait materi muatan pasal $2 \mathrm{~d}$ yang dinilai memberikan pembatasan hak kebebasan berekspresi dan hak atas informasi yang merupakan HAM setiap masyarakat.

Hak kebebasan berekspresi -dalam hal ini, hak atas informasi- merupakan hak yang sangat penting dan mendasar. Hal ini disampaikan bahkan sebelum disahkannya Deklarasi Universal Hak Asasi Manusia oleh PBB. Pada sidang pertamanya tanggal 14 Desember 1946, Majelis Umum PBB mengeluarkan Resolusi Nomor 59 (I) yang menyatakan bahwa hak atas informasi merupakan hak asasi manusia yang mendasar dan merupkan standar dari semua kebebasan yang dinyatakan "suci" oleh PBB. ${ }^{18}$ Pengakuan terhadap hak kebebasan berkespresi tertuang dalam instrument hokum internasional. Deklarasi Umum Hak Asasi Manusia (DUHAM) dan Kovenan Internasional Hak-Hak Sipil dan Politik (ICCPR) merupakan beberapa instrument hukum yang diratifikasi oleh negara-negara anggota Perserikatan Bangsa Bangsa (PBB), dan secara formal diakuisebagai salah satu instrument HAM internasional. Pasal 19 DUHAM sebagai panduan HAM dunia menyebutkan:

"Setiap orang berhak atas kebebasan mempunyai dan mengeluarkan pendapat dan berekspresi; dalam hal ini termasuk kebebasan menganut pendapat tanpa mendapat gangguan, dan untuk mencari, menerima dan menyampaikan keterangan-keterangan dan pendapat dengan cara apa pun dan dengan tidak memandang batas-batas."

Ketentuan pasal 19 DUHAM ini tak serta merta tanpa batasan, sebab Pasal 29 ayat (2) DUHAM telah membatasi ketentuan dalam pasal 19. Menurut Pasal 29 ayat (2) DUHAM, pembatasan kebebasan yang ditetapkan undang-undang yang tujuannya semata-mata untuk menjamin pengakuan serta penghormatan yang tepat terhadap hak-hak dan kebebasankebebasan orang lain, dan untuk memenuhi syarat-syarat yang adil dalam hal kesusilaan, ketertiban, dan kesejahteraan umum dalam suatu masyarakat yang demokratis. DUHAM mengakui pembatasan terhadap kebebasan dengan persyaratan yang harus diikuti. Selain itu, Pasal 19 ayat (3) ICCPR yang menyebutkan bahwa hak kebebasan berekspresi sebagaimana terdapat dalam Pasal 19 ayat (2) juga menimbulkan tanggung jawab khusus. Oleh karena itu, dapat dikenai pembatasan tertentu. Tetapi batasan itu juga dibatasi, sebab hanya dapat dilakukan apabila; sesuai dengan hukum, diperlukan untuk menghormati hak atau nama baik orang lain serta melindungi keamanan nasional atau ketertiban umum atau kesehatan atau moral umum. ${ }^{19}$

Untuk mencegah adanya definisi pembatasan yang terlalu luas, yang berpotensi bukan lagi sekadar membatasi melainkan mengarah kepada pelanggaran hak itu sendiri, ada syaratsyarat khusus dalam melakukan pembatasan. Syarat-syarat ini disebut uji tiga rangkai (three part test). Uji tiga rangkai telah diakui oleh UN Human Rights Commite dalam Mukong V. Cameroon dan oleh European Court of Human Rights dalam Hungarian Civil Liberties Union V. Hungary. ${ }^{20}$ Uji tiga rangkai ini digunakan sebagai indicator untuk melihat tepat atau tidaknya pembatasan HAM. Dalam metode uji tiga rangkai disebutkan bahwa (1) pembatasan itu harus dilakukan hanya melalui undang - undang; (2) pembatasan dilakukan harus atas tujuan yang sah sebagaimana telah disebutkan dalam Pasal 19 ayat (3) ICCPR yakni harus menghromati hak atau nama baik orang lain dan tidak memberikan ancaman terhadap keamanan nasional, ketertiban,

18 Marwandianto and Hilmi Ardani Nasution, "Hak Atas Kebebasan Berpendapat Dan Berekspresi Dalam Koridor Penerapan Pasal 310 Dan 311 KUHP," Jurnal HAM 11, no. 1 (2020): 1, https://doi.org/10.30641/ham.2020.11.1-25.

19 ELSAM, Buku Saku Kebebasan Berekspresi Di Internet, Seri Internet Dan HAM, vol. 53 (Jakarta: Lembaga Studi dan Advokasi Masyarakat (ELSAM), 2013), 18-19.

20 ELSAM et al., "Pidana Penghinaan Adalah Pembatasan Kemerdekaan Berpendapat Yang Inkonstitusional: Amicus Curiae (Komentar Tertulis)" (Jakarta, 2010), 15. 
Kosmik Hukum Vol. 21 No. 2 (2021): 86-97

E-ISSN: 2655-9242 | P-ISSN: 1411-9781

DOI: 10.30595/kosmikhukum.v21i2.9947

kesehatan, dan moral umum; (3) pembatasan itu harus benar-benar diperlukan untuk menjamin dan melindungi tujuan yang sah tersebut. ${ }^{21}$

Indikator lain yang dapat dilihat untuk melihat suatu pembatasan HAM tepat atau tidak dapat dilihat pada Prinsip Siracusa. Berdasarkan Prinsip Siracusa, pembatasan hak dapat dikatakan proporsional harus memperhatikan hal-hal berikut:

a. Presribed by Law, pembatasan hak harus diatur dalam hukum agar pembatasam yang berlaku tidak semena-mena dan memiliki alasan. Dimana hukum yang mengatur juga harus jelas dan diketahui semua orang serta penegakan hukumnya berjalan efektif;

b. In a demoratic society, pembatasan hak yang dilakukan harus ditetapkan sesuai dengan nilainilai demokrasi;

c. Public order, pembatasan hak dilakukan semata-mata untuk mewujudkan ketertiban umum;

d. Public health, pembatasan hak dapat dilakukan jika terdapat tindakan yang dapat membahayakan kesehatan masyarakat atau individu;

e. Public morals, pembatasan hak harus sesuai dengan nilai-nilai moral yang ada di masyarakat;

f. National Security, pembatasan hak harus berdasarkan kemanan nasional yang dilakukan dengan alasan untuk menjaga eksistensi sebuah negara;

g. Public Safety, pembatasan hak dilakukan dengan alasan kemananan fisik maupun properti seseorang;

h. Rights and freedoms of others "of tor the" rights or reputation of others, pembatasan hak dapat harus dilakukan unyuk melindungi hak dan kebebasan orang lain serta hak atau reputasi seseorang;

i. Restriction or public trial, proses peradilan harus dilakukan sesuai dengan hukum yang berlaku tanpa campur tangan publik dan wartawan untuk mencegah penghakiman oleh publik yang mengancam keadilan sebuah peradilan. ${ }^{22}$

Maklumat Kapolri No. 1/Mak/I/2021 dikeluarkan hanya berdasarkan keputusan 6 Menteri dan Lembaga dalam bentuk Keputusan Bersama, serta bukan merupakan produk peraturan perundang-undangan sehingga masih belum memenuhi persyaratan yang diatur oleh hukum untuk melakukan pembatasan HAM masyarakat, dalam bentuk pelarangan mengakses, mengunggah, dan menyebarluaskan konten terkait FPI baik melalui website maupun media sosial.Keputusan pada dasarnya dapat diartikan secara luas dan sempit. Dalam arti yang luas, keputusan dapat mengandung arti sebagai peraturan (regels), keputusan (beschikking) dan tetapan (vonnis). Sedangkan dalam arti yang sempit, keputusan hanya diartikan sebagai suatu hasil kegiatan penetapan atau pengambilan keputusan administratif (beshikkinng). ${ }^{23}$ Keputusan (beschikking) selalu bersifat individual dan konkrit (individual and concrete). ${ }^{24}$ Selain itu, keputusan (beschikking) juga bersifat sekali-selesai (enmahlig). ${ }^{25}$ Hal ini dapat diartikan bahwa suatu keputusan (beschikking) pada umumnya merupakan keputusan yang menyangkut individuindividu tertentu yang secara konkret disebut namanya dalam keputusan (beschikking) tersebut sebagai sasarannya. Keputusan bersama terkait FPI itu sendiri jika dilihat merupakan suatu norma yang berbentuk keputusan yang bersifat individual, konkret, dan sekali selesai. Namun, isinya berpotensi berlaku secara terus-menerus dan bukan hanya menyasar FPI saja sebagai objek pengaturannya, namun juga masyarakat.Maklumat Kapolri ini sebagai tindak lanjut atas keputusan tersebut justru mengatur lebih luas. Hal tersebut tertuang pada pasal 5 keputusan bersama tersebut yang meminta kepada masyarakat untuk tidak terpengaruh, terlibat dalam kegiatan, penggunaan simbol dan atribut FPI. Serta melaporkan kepada aparat penegak hukum setiap melihat ada penggunaan simbol dan atribut FPI. Pasal 2d juga menyebutkan larangan bagi masyarakat untuk mengakses, mengunggah, dan menyebarluaskan konten yang terkait dengan FPI, baik melalui website maupun media sosial. Larangan tersebut artinya membatasi hak

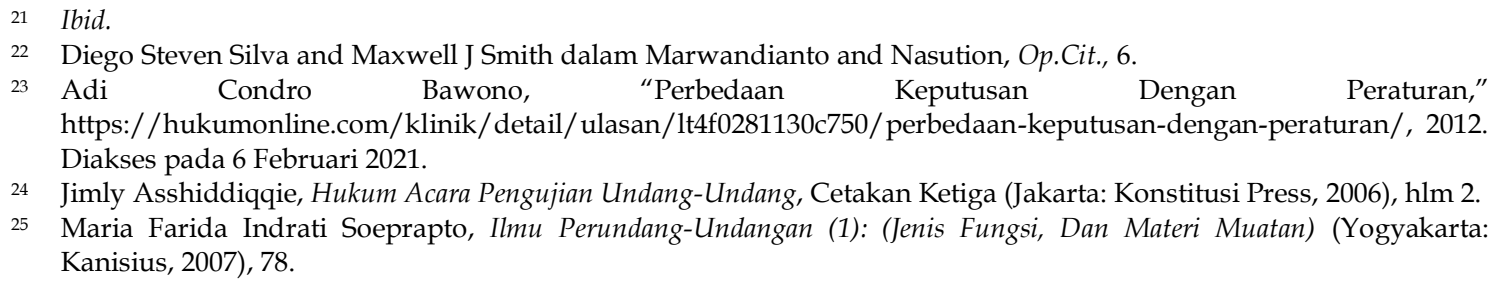


kebebasan berekspresi masyarakat khususnya hak atas informasi yang mana seharusnya dilindungi sebagai HAM dalam konstitusi NRI.

Penggunaan frasa "Keputusan Bersama" kurang tepat dan tidak teoretis, karena semestinya untuk mengatur masyarakat tidak menggunakan bentuk keputusan (beschikking). Dalam hal ini, Maklumat Kapolri No. 1/Mak/I/2021 yang hanya disandarkan pada Keputusan Bersama tersebut tentu tidak memenuhi indikator pembatasan HAM dalam Prinsip Siracusa yakni Presribed by Law. Jika ditinjau dari uji tiga rangkai, pertama perlu diketahui bahwa Maklumat Kapolri bukan merupakan Undang-Undang atau bahkan Peraturan Perundangundangan sehingga pembatasan tersebut tidak seharusnya diatur di dalam sebuah maklumat yang dasar hukumnya hanya berupa keputusan bersama. Kemudian dalam Pasal 19 ayat (3) ICCPR menyebutkan pembatasan atas tujuan yang sah yaitu apabila dilakukan untuk menghormati hak atau nama baik orang lain serta untuk melindungi keamanan nasional atau ketertiban umum atau kesehatan atau moral umum. Pasal 2 Maklumat tersebut telah menyebutkan bahwa demi perlindungan dan menjamin keamanan, juga keselamatan masyarakat sebagai alasan yang melatarbelakangi muatan norma di dalam maklumat. Hal ini menjadi tidak jelas apakah demi keamanan nasional atau ketertiban umum yang menjadi tujuan yang sah (legitimate aim). Indikator kedua ini tidak dapat dilepaskan dari yang ketiga yaitu adanya kebutuhan (necessity) sehingga benar-benar diperlukan pembatasan dalam rangka menjamin dan melindungi tujuan yang sah tersebut. ${ }^{26}$ Artinya maklumat Kapolri tersebut juga tidak memenuhi indikator pembatasan HAM berdasar syarat uji tiga rangkai (three past test).

Tujuan dikeluarkannya Maklumat Kapolri No. 1/Mak/I/2021 sebagaimana telah dijelaskan diatas, tertuang dalam pasal 2 maklumat tersebut, yakni untuk memberikan perlindungan dan mejamin keamanan serta keselamatan masyarakat. Dimana menurut Menteri Koordinator Bidang Politik, Hukum dan Kemanan, Mahfud MD, memyebutkan alasan dibubarkannya FPI karena FPI tidak mengurus berkas-berkas perpanjangan izin mendirikan organisasi ke Kementerian Hukum dan HAM sejaktahun 2019.27 Adapun terdapat permasalahan dalam Anggaran Dasar/Anggaran Rumah Tangga (AD/ART) FPI, yakni terkait pencatuman kata khilafah dalam AD/ART tersebut. ${ }^{28}$ Hal yang menjadi pertanyaan adalah ketika masyarakat masih mengakses informasi/konten terkait FPI di internet apakah menimbulkan sebuah pelanggaran HAM yang mengakibatkan tidak menghromati hak atau nama baik orang lain dan memberikan ancaman terhadap keamanan nasional, ketertiban, kesehatan, dan moral umum sesuai dengan Pasal 19 ayat (3). Lebih lanjut, tindakan pembatasan terhadap akses interntet oleh pemerintah telah diatur dalam Pasal 40 ayat (2a) dan (2b) UU No. 19 Tahun 2016 tentang Perubahan Atas Undang-Undang Nomor 11 Tahun 2008 tentang Informasi dan Transaksi Elektronik yang menyatakan:

(2a) Pemerintah wajib melakukan pencegahan penyebarluasan dan penggunaan Informasi Elektronik dan/atau Dokumen Elektronik yang memiliki muatan yang dilarang sesuai dengan ketentuan peraturan perundang-undangan.

(2b) Dalam melakukan pencegahan sebagaimana dimaksud pada ayat (2a), Pemerintah berwenang melakukan pemutusan akses dan/atau memerintahkan kepada Penyelenggara Sistem Elektronik untuk melakukan pemutusan akses terhadap Informasi Elektronik dan/atau Dokumen Elektronik yang memiliki muatan yang melanggar hukum.

Hal tersebut tentu tidak proporsional karena sebuah maklumat lembaga yang disandarkan pada keputusan bersama yang jelas bukan peraturan perundang-undangan, melakukan pembatasan HAM sehingga belum memenuhi persyaratan yang diatur oleh undang-undang tersebut.

\section{Tinjauan Maklumat Kapolri No. 1/Mak/I/2021 dalam Perspektif Kebebasan Pers}

\footnotetext{
Communication No. 458/1991, A. W. Mukong v. Cameroon (Views adopted on 21 July 1994)

27 Adhi Wicaksono, “SKB FPI Organisasi Terlarang Ditandatangani 6 Pejabat Tinggi," CNN Indonesia, 2020, https://cnnindonesia.com/nasional/20201230154923-12-587958/skb-fpi-organisasi-terlarang-ditandatangani-6pejabat-tinggi. Diakses pada 6 Februari 2021.

$28 \quad$ Ibid.
} 
Kosmik Hukum Vol. 21 No. 2 (2021): 86-97

E-ISSN: 2655-9242 | P-ISSN: 1411-9781

DOI: 10.30595/kosmikhukum.v21i2.9947

Pers menurut Pasal 1 angka 1 UU No. 40 Tahun 1999 tentang Pers dapat didefinisikan sebagai lembaga sosial dan wahana komunikasi massa yang melaksanakan kegiatan jurnalistik yang meliputi mencari, memperoleh, memiliki, menyimpan, mengolah, dan menyampaikan informasi baik dalam bentuk tulisan, suara, gambar, suara dan gambar, serta data dan grafik maupun dalam bentuk lainnya dengan menggunakan media cetak, media elektronik, dan segala jenis saluran yang tersedia.

Kebebasan pers sendiri secara konstitusional telah diatur dalam Pasal 28F UUD NRI 1945 yang mengatur hak atas kebebasan berkomunikasi dan memperoleh informasi untuk mengembangkan pribadi dan lingkungan sosialnya, serta hak untuk mencari, memperoleh, memiliki, menyimpan, mengolah, serta menyampaikan informasi dengan menggunakan segala jenis saluran yang tersedia. Kemudian, kebebasan pers kembali dikuatkan dengan diundangkannya UU No. 40 Tahun 1999 tentang Pers yang menggantikan UU No. 11 Tahun 1996 tentang Ketentuan-Ketentuan Pokok Pers. Beberapa pasal yang menegaskan asas, fungsi dan pentingnya peranan pers dalam undang-undang tersebut adalah sebagai berikut:

Pasal 2:

Kemerdekaan pers adalah salah satu wujud kedaulatan rakyat yang berasaskan prinsip-prinsip demokrasi, keadilan, dan supermasi hukum.

Pasal 3 ayat (1):

Pers nasional mempunyai fungsi sebagai media informasi, pendidikan, hiburan, dan kontrol sosial.

Pasal 6:

Pers nasional melaksanakan peranan sebagai berikut:

a. memenuhi hak masyarakat untuk mengetahui;

b. menegakkan nilai-nilai dasar demokrasi, mendorong terwujudnya supermasi hukum, dan hak asasi manusia, serta menghormati kebhinekaan;

c. mengembangkan pendapat umum berdasarkan informasi yang tepat, akurat, dan benar;

d. melakukan pengawasan, kritik, korelasi, dan saran terhadap hal-hal yang berkaitan dengan kepentingan umum;

e. memperjuangkan keadilan dan kebenaran.

Kemudian, kemerdekaan pers pada dasarnya juga telah dijamin sebagai hak asasi warga negara sebagaimana disebutkan dalam pasal 4 ayat (1) UU No. 40 Tahun 1999 tentang Pers. Indonesia sebagai negara demokrasi memiliki masalah yang serius mengenai penyebaran konten hoax atau berita palsu khususnya melalui media sosial. Salah satu media sosial yang sering ramai dengan pemberitaan adalah Twitter. Beberapa kali tagar mengenai FPI ada di tren atas media sosial Twitter. Respon masyarakat pun beragam dan tidak sedikit yang termakan hoax. Potensi adanya pembatasan hak atas kebebasan berekspresi yang ada di dalam Maklumat Kapolri No. 1/Mak/I/2021 tentang Kepatuhan Terhadap Larangan Kegiatan, Penggunaan Simbol dan Atribut serta Penghentian Kegiatan FPI merupakan suatu kebijakan yang didasarkan atas diskresi kapolri dalam mengatasi beredarnya konten-konten mengenai FPI yang menurut mereka tidak sesuai. Namun, hal itu menjadi masalah karena dalam rumusan pasal 2d memberlakukan larangan penyebaran konten apapun yang terkait FPI tanpa syarat. Maka, larangan dapat berlaku bagi siapa saja termasuk jurnalis atau pers, dan berlaku untuk konten apa saja meskipun konten tersebut bukan berita palsu. Selama ini upaya yang dilakukan pemerintah ketika menangani penyebaran berita palsu adalah memblokir situs internet yang menjadi sumber informasi palsu. ${ }^{29}$ Di dalam ketentuan UU ITE juga menindak penyebaran konten yang muatannya terlarang dengan cara memutuskan akses ke konten tersebut.

Pasal 2d Maklumat Kapolri No. 1/Mak/I/2021 tentang Kepatuhan Terhadap Larangan Kegiatan, Penggunaan Simbol dan Atribut serta Penghentian Kegiatan FPI melarang masyarakat untuk mengakses, mengunggah, dan menyebarluaskan konten-konten yang terkait dengan FPI melalui internet. Hal ini tentu bertentangan dengan UU No. 40 Tahun 1999 tentang Pers yang

29 Kurniawan Hari Siswoko, “Kebijakan Pemerintah Menangkal Penyebaran Berita Palsu Atau 'Hoax,'” Jurnal Muara Ilmu Sosial, Humaniora, Dan Seni 1, no. 1 (2017): 13, https://doi.org/10.24912/jmishumsen.v1i1.330. 
telah menjamin kebebasan pers. Pasal 4 ayat (3) undang-undang tersebut menyebutkan bahwa dalam menjamin kebebasan pers, maka pers nasional berhak dalam mencari, memperoleh, maupun menyebarluaskan suatu informasi.

Muatan maklumat tersebut yang berpotensi mengancam kebebasan pers memicu respon dari sejumlah pegiat demokrasi. Komunitas Pers bereaksi dengan meminta Kepala Kepolisian RI Idham Azis mencabut Pasal 2d yang ada di dalam Maklumat Nomor: Mak/1/I/2021. ${ }^{30}$ Adalah Aliansi Jurnalis Indonesia (AJI), Persatuan Wartawan Indonesia Pusat, Ikatan Jurnalis Televisi Indonesia, Pewarta Foto Indonesia, Forum Pemimpin Redaksi, dan Asosiasi Media Siber Indonesia yang menentang pasal $2 \mathrm{~d}$ dalam maklumat tersebut.

Sementara itu, Polri merespon kegelisahan Komunitas Pers dengan mengeluarkan Surat Telegram Kapolri Nomor ST 1/I/HUM.3.4.5/2021 tertanggal 4 Januari 2021. Polri memastikan Maklumat Kapolri Pasal 2d tentang Front Pembela Islam (FPI) tidak ditujukan kepada media massa. Sepanjang pemberitaan sesuai Kode Etik Jurnalistik, kebebasan pers tetap mendapat jaminan konstitusional. ${ }^{31}$ Namun tetap saja, ruang gerak pers seolah dibatasi dalam mencari, memperoleh, maupun menyebarluaskan suatu informasi.

Adanya pers memfasilitasi masyarakat untuk menerima informasi yang benar. Jika ruang gerak pers terlalu terbatas, atau bahkan dilarang, ada hak asasi warga negara yang terenggut sebagaimana yang dipermasalahkan dalam Maklumat Kapolri tersebut. Bahkan dengan adanya maklumat tersebut, kemerdekaan pers tidak dapat lagi dikatakan sebagai hak asasi warga negara sebagaimana dijamin dalam pasal 4 ayat (1) UU No. 40 Tahun 1999 tentang Pers.

Dengan adanya maklumat tersebut, pers yang pada hakikatnya merupakan lembaga sosial dan wahana komunikasi massa yang melaksanakan kegiatan jurnalistik yang meliputi mencari, memperoleh, memiliki, menyimpan, mengolah, dan menyampaikan informasi baik dalam bentuk tulisan, suara, gambar, suara dan gambar, serta data dan grafik maupun dalam bentuk lainnya dengan menggunakan media cetak, media elektronik, dan segala jenis saluran yang tersedia tentu akan terganggu ruang geraknya serta dapat memnbatasi hak asasi warga negara sebagaimana telah dijamin dalam Pasal 28F UUD NRI 1945 dan pasal 4 ayat (1) UU No. 40 Tahun 1999 tentang Pers.

\section{Penutup}

Maklumat Kapolri No. 1/Mak/I/2021 tentang Kepatuhan Terhadap Larangan Kegiatan, Penggunaan Simbol dan Atribut serta Penghentian Kegiatan FPI, terutama pada Pasal 2d yang melarang mengakses, mengunggah, dan menyebarluaskan konten terkait FPI melalui internet dianggap telah membatasi hak asasi manusia khusunya hak atas kebebasan berekspresi. Hak atas kebebasan berekspresi merupakan hak yang dilindungi oleh konstitusi maupun UndangUndang di Indonesia. Namun, hak tersebut bukan hak yang mutlak, melainkan dapat dibatasi. Untuk mengukur sejauh apa pembatasan yang dapat dilakukan, ada dua indikator yang dapat digunakan yaitu uji tiga rangkai (three part test) dan prinsip siracusa. Berdasarkan analisis materi muatan Maklumat Kapolri No. 1/Mak/I/2021 menggunakan prinsip tersebut, didapati bahwa pembatasan hak atas kebebasan berekspresi yang dimuat di dalamnya tidak memenuhi syarat yang telah diatur. Tidak hanya itu, maklumat tersebut juga dirasa membatasi kemerdekaan pers yang telah dijamin dalam pasal 28F UUD NRI 1945 dan UU No. 40 Tahun 1999 tentang Pers. pers yang pada hakikatnya merupakan lembaga sosial dan wahana komunikasi massa yang melaksanakan kegiatan jurnalistik yang meliputi mencari, memperoleh, memiliki, menyimpan, mengolah, dan menyampaikan informasi baik dalam bentuk tulisan, suara, gambar, suara dan gambar, serta data dan grafik maupun dalam bentuk lainnya dengan menggunakan media cetak,

30 Imam Hamdi, “Organisasi Pers Hingga Ormas Sipil Kritik Maklumat Kapolri Soal FPI,” Tempo, 2021, https://nasional.tempo.co/read/1419594/organisasi-pers-hingga-ormas-sipil-kritik-maklumat-kapolri-soalfpi/full\&view=ok. Diakses pada 27 Februari 2021.

31 Adi Anugrahadi, "Polri: Maklumat Kapolri Soal FPI Bukan Untuk Pers Dan Media Massa," liputan6, 2021, https://www.liputan6.com/news/read/4448993/polri-maklumat-kapolri-soal-fpi-bukan-untuk-pers-dan-mediamassa\#: :text=polri\%3a-maklumat-kapolri-soal-fpi-bukan-untuk-pers-dan-media-massa,-adyanugrahadi\&text=liputan6.com\%2c. Diakses pada 27 Februari 2021. 
Kosmik Hukum Vol. 21 No. 2 (2021): 86-97

E-ISSN: 2655-9242 | P-ISSN: 1411-9781

DOI: 10.30595/kosmikhukum.v21i2.9947

media elektronik, dan segala jenis saluran yang tersedia tentu akan terganggu ruang geraknya dengan adanya maklumat tersebut.

Oleh karena itu, penulis memberi saran semestinya Kapolri memperbaharui maklumat tersebut sesuai maksud dan tujuan maklumat tersebut diterbitkan yakni dengan untuk memberikan perlindungan dan mejamin keamanan serta keselamatan masyarakat, atau setidaknya mencabut pasal $2 \mathrm{~d}$ dalam maklumat tersebut yang melarang mengakses, mengunggah, dan menyebarluaskan konten terkait FPI melalui internet dianggap telah membatasi hak asasi manusia khusunya hak atas kebebasan berekspresi. Hal ini agar seluruh tindakan hukum yang ada di negara ini sesuai dengan prinsip negara hukum dan hak asasi manusia. Jangan sampai instrumen hukum yang digunakan untuk memberikan perlindungan dan jaminan kepada masyarakat justru merenggut hak asasi masyarakat itu sendiri.

\section{Daftar Pustaka}

Anugrahadi, Adi. "Polri: Maklumat Kapolri Soal FPI Bukan Untuk Pers Dan Media Massa". dikutip dari laman: https://www.liputan6.com/news/read/4448993/polri-maklumatkapolri-soal-fpi-bukan-untuk-pers-dan-media-massa\#: :text=polri\%3a-maklumat-kapolrisoal-fpi-bukan-untuk-pers-dan-media-massa,-ady-anugrahadi\&text=liputan6.com $\% 2 \mathrm{c} \quad$; diakses pada 27 Februari 2021.

Asshiddiqqie, Jimly. Hukum Acara Pengujian Undang-Undang. Cetakan Ketiga. Jakarta: Konstitusi Press, 2006.

Bawono, Adi Condro. "Perbedaan Keputusan Dengan Peraturan" dikutip dari laman: https://hukumonline.com/klinik/detail/ulasan/lt4f0281130c750/perbedaan-keputusandengan-peraturan/; diakses pada 6 Februari 2021.

Bachtiar. Metode Penelitian Hukum. Tangerang Selatan: Unpam Press, 2018.

ELSAM. Buku Saku Kebebasan Berekspresi Di Internet. Seri Internet Dan Ham. Vol. 53. Jakarta: Lembaga Studi Dan Advokasi Masyarakat (Elsam), 2013.

ELSAM, ICJR, IMDLN, PBHI, and YLBHI. Pidana Penghinaan Adalah Pembatasan Kemerdekaan Berpendapat Yang Inkonstitusional: Amicus Curiae (Komentar Tertulis). Jakarta, 2010.

Farida Indrati Soeprapto, Maria. Ilmu Perundang-Undangan (1): (Jenis Fungsi, Dan Materi Muatan). Yogyakarta: Kanisius, 2007.

Farisa, Fitria Chusna. "6 Alasan Pemerintah Bubarkan Dan Larang Kegiatan FPI...". Dikutip dari laman: https://nasional.kompas.com/read/2020/12/30/14545951/6-alasan-pemerintahbubarkan-dan-larang-kegiatan-fpi?page=all; diakses pada 30 Januari 2021.

Hamdi, Imam. "Organisasi Pers Hingga Ormas Sipil Kritik Maklumat Kapolri Soal FPI". Dikutip dari laman: https://nasional.tempo.co/read/1419594/organisasi-pers-hingga-ormas-sipilkritik-maklumat-kapolri-soal-fpi/full\&view=ok; diakses pada 27 Februari 2021.

Marwandianto and Hilmi Ardani Nasution, Hak atas Kebebasan Berpendapat dan Berekspresi Dalam Koridor Penerapan Pasal 310 Dan 311 KUHP, Jurnal HAM 11, No. 1 (2020): 1-25.

Matompo, Osgar S. Pembatasan Terhadap Hak Asasi Manusia dalam Prespektif Keadaan Darurat, Jurnal Media Hukum 21, No. 1 (2014): 57-72.

Mertokusumo, Sudikno. Mengenal Hukum Suatu Pengantar [Edisi Revisi]. Yogyakarta: Cahaya Atma Pustaka, 2010.

Nasution, Adnan Buyung. Arus Pemikiran Konstitusionalisme: Hak Asasi Manusia Dan Demokrasi. Vol. 2. Jakarta: Kata Hasta Pustaka, 2007.

Perangin-Angin, Ita Iya Pulina., Rahayu, Nuswantoro Dwiwarno, "Kewajiban dan Tanggungjawab Negara Memberikan Perlindungan Hukum Terhadap Perempuan Korban Revenge Porn Di Indonesia". Diponegoro Law Journal 8, No. 1 (2019): 457-83.

Rahmanto, Tony Yuri. "Kebebasan Berekspresi Dalam Perspektif Hak Asasi Manusia: Perlindungan, Permasalahan Dan Implementasinya Di Provinsi Jawa Barat". Jurnal Hak 
Asasi Manusia 7, No. 1 (2016): 45-53.

Setiyani and Joko Setiyono. "Penerapan Prinsip Pertanggungjawaban Negara terhadap Kasus

Pelanggaran Ham Etnis Rohingya di Myanmar". Jurnal Pembangunan Hukum Indonesia 2, No. 2 (2020): 261-274.

Smith; Rhona K. M.; At.Al. Hukum Hak Asasi Manusia. Yogyakarta: Pusat Studi Hak Asasi Manusia Universitas Islam Indonesia (Pusham UII), 2008.

Siswoko, Kurniawan Hari. "Kebijakan Pemerintah Menangkal Penyebaran Berita Palsu atau 'Hoax', Jurnal Muara Ilmu Sosial, Humaniora, Dan Seni 1, No. 1 (2017): 13-19.

Wicaksono, Adhi. "SKB FPI Organisasi Terlarang Ditandatangani 6 Pejabat Tinggi". Dikutip dari laman: $\quad$ https://cnnindonesia.com/nasional/20201230154923-12-587958/skb-fpiorganisasi-terlarang-ditandatangani-6-pejabat-tinggi; diakses pada 30 Janurai 2021. 